\title{
DMFC water management in presence of heat sources
}

\author{
Halitim S. Houria ${ }^{1 *}$, Zitouni Bariza ${ }^{1,2}$, Haddad Djamel ${ }^{1}$, Benmoussa Hocine ${ }^{1}$. \\ ${ }^{1}$ Department of mechanical, Faculty of technology, University of Hadj Lakhdar, Batna, Algeria \\ ${ }^{2}$ Department of food Technology, Institute of veterinary sciences and agricultural sciences, \\ University of Hadj Lakhdar, Batna.
}

Email: halitim.siham@yahoo.com

\begin{abstract}
A heat and mass transfer numerical study is conducted in DMFC in presence of the heat sources. The model is used to investigate the current density effect at operation conditions (temperature) and at water, methanol, carbon dioxide and oxygen concentration. For the numerical resolution, governing equations are discretized by the finite volume method. A program written in FORTRAN language was developed in order to obtain the temperature, water, methanol, oxygen and carbon dioxide fields. The results show that there is a temperature rise at the membrane which involves the membrane drying. However, for the water concentration field, a dehydration problem solution in the membrane is considered. The current density is the key parameter simulation since it is present in Joules effect terms.
\end{abstract}

Keywords: DMFC, Methanol, Heat Source, Temperature, FORTRAN.

\section{INTRODUCTION}

The Fuel cells are devices which harness electrical energy from electrochemical. Direct methanol fuel cell (DMFC) is one. It has several advantages such; higher energy density, easy liquid fuel storage and the simple structure. The technical issues are related to the transport. This transport not only affects the performance and stability of DMFC operation, but also influences the DMFC energy density. General descriptions of mass and heat transport processes are developed.

A several studies about various heat sources resulting from DMFC reagents (methanol, oxygen and water) and products (water and carbon dioxide) is presented.

The literature reviewed is selected by the source term type. Others in reference [1] examined heat transfer by natural convection. The source term is composed by the flow resistance, the electrochemical reactions, the over potential, the entropy change due to the electrochemical reaction and the methanol reaction cathode heat loss.

Others in paper [2] studied the oxygen starvation. The source terms used are those due to; electrochemical reaction, Joule effect, water condensation or evaporation and the dissolved water and fuel adsorption or desorption to the electrolyte.

The results in the studies $[3,18,20]$ showed that the mass and heat transport affect the DMFC performance and depends strongly on the methanol concentration in the tank. The studied works $[4,5,12,19]$ focuses on the evaporation and condensation effects, water and fuel management in a DMFC. [5] studied the effect of a forced air flow at the cathode channel. The others of reference [6] considered the effect of diffusion, electro-osmotic drag and convection. A twodimensional model was developed with the mass transport in two phases for a DMFC $[8,9]$. Numerical results show that methanol mass transfer is dominated by the resistance in the porous anode structure, which is affected by the physical properties of the porous medium, such as porosity, permeability and contacting angle.

A fluid dynamics model (CFD) is developed to study the influence of geometric and operating parameters on DMFC performance. Temperature, methanol concentration and the methanol flow rate are selected as operating parameters in papers [10, 11, 13, 14 and 21]. The model in [17] presented a two-phase model, multi-components components in three dimensions to a liquid supplying DMFC methanol.

The modelling field comprises the membrane, two catalyst layers, two diffusion layers and two channels. For the electrochemical kinetics, the Tafel equation incorporating the effects of the two phases is used both on the side of the cathode and the anode.

However, all these articles contain at least one heat source term such as in papers [13], the source term due to the flow resistance. At [8, 17 and 21] papers, in addition to the flow resistance term, electrochemical reaction heat source. Additively to the term mentioned above, source terms due to mass transfer are in [1, 3, 4, 9 and 14]. In addition, reference [11] considered phase change, in addition to terms previously seen.

The source term due to the phase change comprises at least more differences due to model study; condensation / evaporation [19] or latent heat [12]. The mass source term 
also includes it in some review the mass transfer and chemical reactions [14]. The heat generation is caused by the over potential and the entropy change [6]. The source term due to the phase change comprises at least more differences due to model study; condensation / evaporation [19] or latent heat [12]. The analytical model selected [8, 13, 17 and 21] is rapidly implemented and is therefore suitable for inclusion in real-time system level DMFC calculations.

In this study, a numerical simulation is developed in order to predict the DMFC behaviour when the heat source is variable; the heat source terms due to the flux resistance, that due to the electrochemical reactions and that due to Joules effect. Both temperature and $\left(\mathrm{H}_{2} \mathrm{O}, \mathrm{O}_{2}, \mathrm{CH}_{3} \mathrm{OH}, \mathrm{CO}_{2}\right)$ mass fields are visualized.

\section{MATHEMATICAL MODEL}

The study focuses on a DMFC elementary cell coupling between the electrochemical and dynamic model. Gas channels are considered continuum, while the diffusion layers, catalyst and the membrane are porous media. Fig.1 shows a physical considered here, which can be divided into seven regions:

(1) Anode channel (ac);

(2) Anode diffusion layer (adl);

(3) Anode catalyst layer (acl);

(4) Polymer membrane (mem);

(5) Cathode catalyst layer (ccl);

(6) Cathode diffusion layer (cdl);

(7) Cathode channel (cc).

The following hypotheses are considered: The catalyst layer is treated as an infinitely thin surface. Single phase fluid is homogeneous.

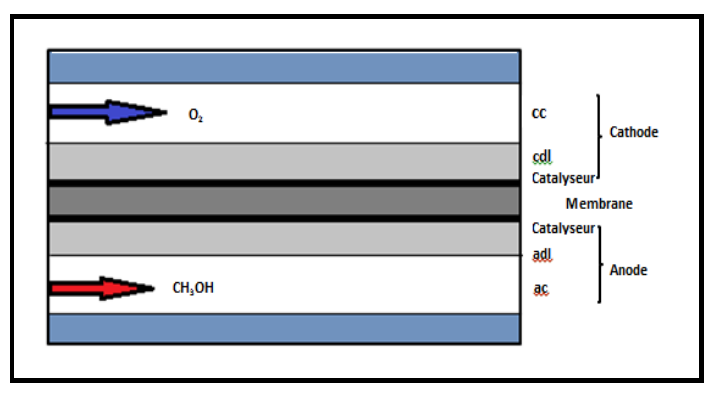

Figure 1. DMFC schematic model.

The principal reactions in a DMFC are the oxidation reaction mainly occurs at the anode catalyst layer and the reduction reaction occurs at the cathode catalyst layer:

Oxidation: $\mathrm{CH}_{3} \mathrm{OH}+\mathrm{H}_{2} \mathrm{O} \rightarrow \mathrm{CO}_{2}+6 \mathrm{H}^{+}+6 e^{-}$

Reduction: $\frac{3}{2} \mathrm{O}_{2}+6 e^{-}+6 \mathrm{H}^{+} \rightarrow 3 \mathrm{H}_{2} \mathrm{O}$

Overall: $\quad \mathrm{CH}_{3} \mathrm{OH}+\frac{3}{2} \mathrm{O}_{2} \rightarrow \mathrm{CO}_{2}+2 \mathrm{H}_{2} \mathrm{O}$

These electrochemical reactions can be summarized as:

$\sum_{\mathrm{k}} \mathrm{S}_{\mathrm{Ri}}^{\mathrm{k}}{ }^{\mathrm{M}}{ }_{\mathrm{k}}^{\mathrm{k}}=\mathrm{n}_{\mathrm{Ri}} \mathrm{e}^{-}$

where $\mathrm{k}, \mathrm{M}_{\mathrm{k}}, \mathrm{S}_{\mathrm{k}}, \mathrm{Z}_{\mathrm{k}}$, and $\mathrm{n}_{\mathrm{Ri}}$ represent species $\mathrm{k}$, chemical formula of species $\mathrm{k}$, stoichiometric coefficient, charge number of species $\mathrm{k}$, and the total number of electrons produced in reaction of oxidation respectively

\section{GOVERNING EQUATIONS}

The governing equations are:

$\frac{\partial(\varepsilon \rho)}{\partial \mathrm{t}}+\nabla(\varepsilon \rho \mathrm{u})=0$

where ' $\varepsilon, \rho$, u' represent porosity factor of the corresponding region, methanol solution density and fluid velocity vector, respectively. The first term on the left side of Eq. (2) is the item of unstable state and the second term on the left side is the item of convection.

$$
\frac{\partial(\varepsilon \rho \mathrm{u})}{\partial \mathrm{t}}+\nabla(\varepsilon \rho \mathrm{u})=-\varepsilon \nabla \mathrm{p}+\nabla(\varepsilon \cdot \mu \nabla \mathrm{u})+\mathrm{S}_{\mathrm{u}}
$$

where ' $\mathrm{S}_{\mathrm{u}}$ ' is momentum source term $\left(\mathrm{N} \mathrm{m}^{-3}\right)$, which is caused by porous media and is zero in the channel. $S_{\mathrm{u}}$ is defined by:

$S_{u}=-\varepsilon \frac{\mu}{k} u$

where ' $\mathrm{k}$ ' is the permeability of porous media $\left(\mathrm{m}^{2}\right)$.

Species conservation

$$
\nabla\left(\partial u C_{k}\right)=\nabla\left(D_{k}^{e f f} \nabla C_{k}\right)+S_{k}
$$

where ' $S_{\mathrm{k}}$ 'is the source term that represented the electrochemical reaction in the anodic catalyst layer when the oxidation reaction of methanol product carbon dioxide and current density and the reduction reaction of oxygen product the water in the cathode catalyst layer.

$$
\mathrm{S}_{\mathrm{k} \text {,reaction }}=\mathrm{M}_{\mathrm{k}} \mathrm{J}_{\mathrm{a}} / 6 \mathrm{~F} \quad \mathrm{k}=\mathrm{CH}_{3} \mathrm{OH}, \mathrm{H}_{2} \mathrm{O}, \mathrm{CO}_{2}
$$

where ' $\mathrm{M}_{\mathrm{k}}$ ' $\left(\mathrm{kg} \mathrm{kmol}^{-1}\right)$ is the molecular weight of species ' $\mathrm{k}$ ', ' $\mathrm{F}$ ' is the Faraday constant $\left(9.6485 \times 10^{7} \mathrm{C} \mathrm{kmol}^{-1}\right)$ and local volumetric current density $\left(\mathrm{A} \mathrm{m}^{-3}\right)$ at the anode defined by $\mathrm{Eq}$. (7).

$$
\mathrm{J}_{\mathrm{a}}=\frac{\eta_{\mathrm{mem}}}{\mathrm{t}_{\mathrm{acl}} \mathrm{R}_{\mathrm{mem}}}
$$

where ' $R_{\text {mem }}$ 'is the area specific resistance of the membrane $\left(\Omega \mathrm{m}^{2}\right)$.

Heat transfer

$$
\nabla\left(\rho \mathrm{C}_{\mathrm{p}} \mathrm{uT}\right)=\nabla(\mathrm{k} \nabla \mathrm{T})+\mathrm{S}_{\mathrm{T}}
$$

For the term source ' $\mathrm{S}_{\mathrm{T}}$ ', different heat generations are involved in the DMFC, including the generations from anodic and cathode electrochemical reactions in the CL, latent heat of the phase change of water and methanol in the porous region and Joule effect. 


\section{RESULTS AND DISCUSSION}

Discussion as mentioned above, the cell is operated at a varied current density of $0.5,1,1.1$, and $1.20\left[\mathrm{~A} \mathrm{~cm}^{-2}\right]$.

\section{NUMERICAL RESOLUTION}

For the equations, numerical resolution, a discretized by the finite volume method is done. The source terms and physical properties are implemented through the program. While the equations for solid-phase, electrolyte potentials, dissolved water, dissolved methanol and liquid water are implemented also in program.

A program written in FORTRAN language was developed in order to obtain the temperature, water, methanol, oxygen and dioxide of carbon fields. To make the numerical implementation more practical, the single-domain approach is used.

\subsection{Effect of the current density on the water flow of cell DMFC}

At a current density, $\mathrm{I}=1,2 \mathrm{~A} / \mathrm{cm}^{2}$, the flow of water flow appears in the input membrane. By decreasing the current density, $\mathrm{I}=1$ to $0,5 \mathrm{~A} / \mathrm{cm}^{2}$, a proportionality is between the current density increase and the field water concentration. But increasing water concentration flow is due to the water production in the catalyst layer of the cathode side and to the transport from the anode side in Figure 2.

\subsection{Species concentration fields}

The field concentration can be seen in Fig.3.The concentration of each species $\left(\mathrm{MO}_{3} \mathrm{OH}, \mathrm{CO}_{2}, \mathrm{H}_{2} \mathrm{O}\right)$, and the location of this last as well as the movement of species between the anode, cathode and membrane. A change in the species concentration in different parts of the cell ensures the reliability of our programming in FORTRAN.

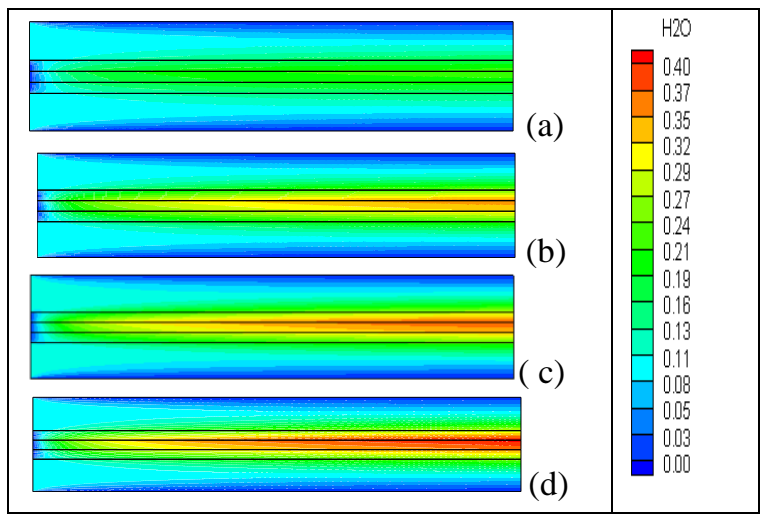

Figure 2. Water concentration field distribution at several current density values. (a): $\mathrm{I}=0.5$, (b): $1,(\mathrm{c}): 1.1$, (d): 1.2 $(\mathrm{A} / \mathrm{cm} 2)$

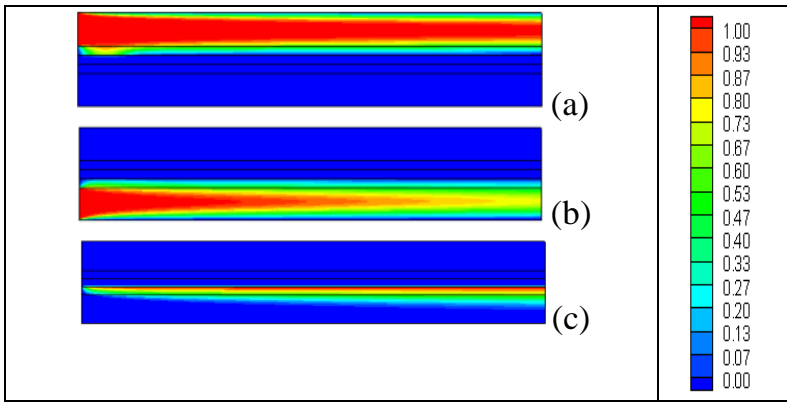

Figure 3. Species field concentration at $\mathrm{I}=1.2(\mathrm{~A} / \mathrm{cm} 2)$. (a): $\mathrm{O}_{2}$ :(b) $\mathrm{CH}_{3} \mathrm{OH}:$ (c) $\mathrm{CO}_{2}$

\subsection{Current density effect at water and temperature distribution}

The current density of the cell is strongly dependent the temperature distribution and the water concentration Fig.4. Indeed, if the current density increases the water concentration and the temperature increase. The cell preservation of the operating conditions is vital.

If the water concentration does not increase a drying occurs in the membrane which entails the increase of the cell resistivity this affects the cell operation.

Certainly, the electrolyte drying disrupted the active sites and makes some catalytic sites not effective because of the ionic strength. It is therefore crucial to ensure a good level of hydration in the cell.

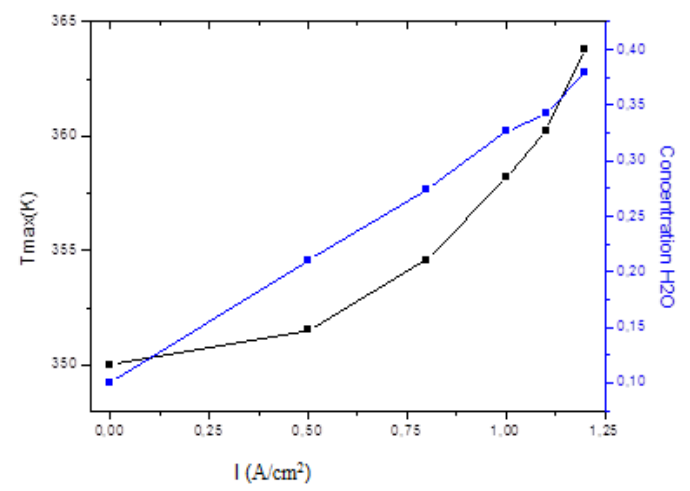

Figure 4. Current density effect at water concentration and temperature distribution.

\section{CONCLUSIONS}

The model is used to investigate the current density effect at operation conditions (temperature) and at water, methanol, dioxide of carbon and oxygen concentration.

The simulations show that the water and reagents concentrations depend on the current density (electrochemical reaction in the catalyst layer). There is proportionality with the current density increasing.

The DMFC performance can be enhanced by increasing the water concentration. It can be also used to improve the cell performance. This results show the solution of dehydration problem in the membrane.

The results show that there is a temperature rise at the membrane which involves drying of the membrane. However, for the water concentration field, a dehydration problem solution in the membrane is considered. The current density is 
the key parameter simulation since it is present in terms of Joules effect.

\section{REFERENCES}

[1] Zou J., He Y., Miao Z., Li X. (2010). Non-isothermal modeling of direct methanol fuel cell, International Journal of Hydrogen Energy, Vol. 35, pp. 7206- 7216. DOI: $10.1016 /$ j.ijhydene.2010.01.123

[2] Yang X.G., Ye Q., Cheng P. (2014). Oxygen starvation induced cell potential decline and corresponding operating state transitions of a direct methanol fuel cell in galvanostatic regime, Electrochimica Acta, Vol. 117, pp. 179- 191. DOI: 10.1016/j.electacta.2013.11.112

[3] Jewett G., Faghri A., Xiao B. (2009). Optimization of water and air management systems for a passive direct methanol fuel cell, International Journal of Heat and Mass Transfer, Vol. 52, pp. 3564-3575. DOI: 10.1016/j.ijheatmasstransfer.2009.03.006

[4] Rice J., Faghri A. (2006). A transient, multi-phase and multi-component model of a new passive DMFC, International Journal of Heat and Mass Transfer, Vol. 49, pp. 4804-4820. DOI:

10.1016/j.ijheatmasstransfer.2006.06.003

[5] Bahrami H., Faghri A. (2010). Transport phenomena in a semi-passive direct methanol fuel cell, International Journal of Heat and Mass Transfer, Vol. 53, pp. 2563-2578. DOI: 10.1016/i.ijheatmasstransfer.2009.12.050

[6] Xu C., Faghri A. (2010). Water transport characteristics in a passive liquid-feed DMFC, International Journal of Heat and Mass Transfer, Vol. 53, pp. 1951-1966. DOI: 10.1016/j.ijheatmasstransfer.2009.12.060

[7] Jung S., Leng Y., Wang C.Y. (2014). Role of $\mathrm{CO}_{2}$ in methanol and water transport in direct methanol fuel cells, Electrochimica Acta, Vol. 134, pp. 35-48. DOI: 10.1016/j.electacta.2014.04.087

[8] He Y.L., Li X.L., Miao Z., Liu Y.W. (2009). Twophase modeling of mass transfer characteristics of a direct methanol fuel cell, Applied Thermal Engineering, Vol. 29, pp. 1998-2008. DOI: 10.1016/j.applthermaleng.2008.10.004

[9] Li X.Y., Yang W.W., He Y.L., Zhao T.S., Qu Z.G. (2012). Effect of anode micro-porous layer on species crossover through the membrane of the liquid-feed direct methanol fuel cells, Applied Thermal Engineering, Vol. 48, pp. 392-401. DOI: 10.1016/j.applthermaleng.2011.10.051

[10] Li X.Y., Yang W.W., He Y.L., Zhao T.S., Qu Z.G. (2012). Effect of anode micro-porous layer on species crossover through the membrane of the liquid-feed direct methanol fuel cells, Applied Thermal Engineering, Vol. 48, pp. 392-401. DOI: 10.1016/j.ijhydene.2009.09.066

[11] Park Y.C., Peck D.H., Donga S.K., Kim S.K., Lim S., Jung D.H., Jang J.H., Lee D.Y. (2011). Operating characteristics and performance stability of $5 \mathrm{~W}$ class direct methanol fuel cell stacks with different cathode flow patterns, International Journal of Hydrogen Energy, Vol. 36, pp. 1853-1861. DOI: 10.1016/j.ijhydene.2010.02.018

[12] Bahrami H., Faghri A. (2012). Start-up and steadystate operation of a passive vapor-feed direct methanol fuel cell fed with pure methanol, International Journal of Hydrogen Energy, Vol. 37, pp. 86416-8658. DOI: 10.1016/j.ijhydene.2012.02.038

[13] Kianimanesh A., Yu B., Yang Q., Freiheit T., Xue D., Park S.S. (2012). Investigation of bipolar plate geometry on direct methanol fuel cell performance, International Journal of Hydrogen Energy, Vol. 37, pp. 18403-18411. DOI: 10.1016/j.ijhydene.2012.08.128

[14] Yu B., Yang Q., Kianimanesh A., Freiheit T., Park S.S., Zhao H., Xue D. (2013). A CFD model with semi-empirical electrochemical relationships to study the influence of geometric and operating parameters on DMFC performance, International Journal of Hydrogen Energy, Vol. 38, pp. 9873-9885. DOI: 10.1016/j.ijhydene.2013.05.118

[15] Kalantari H., Baghalha M. (2014). Analyses of mass and heat transport interactions in a direct methanol fuel cell, International Journal of Hydrogen Energy, Vol. 39, pp. 11224-11240. DOI: 10.1016/j.ijhydene.2014.05.048

[16] Li X., Faghri A. (2011). Local entropy generation analysis on passive high-concentration DMFCs (direct methanol fuel cell) with different cell structures, Energy, Vol. 36, pp. 403-414. DOI: 10.1016/j.energy.2010.10.024

[17] Ge J., Liu H. (2007). A three-dimensional two-phase flow model for a liquid-fed direct methanol fuel cell, Journal of Power Sources, Vol. 163, pp. 907-915. DOI: 10.1016/j.jpowsour.2006.10.014

[18] Vera M.A. (2007). Single-phase model for liquid-feed DMFCs with non-Tafel kinetics, Journal of Power Sources, Vol. 171, pp. 763-777. DOI: $\underline{\text { 10.1016/j.jpowsour.2007.05.098 }}$

[19] Xiao B., Bahrami H., Faghri A. (2010). Analysis of heat and mass transport in a miniature passive and semi passive liquid-feed direct methanol fuel cell, Journal of Power Sources, Vol. 195, pp. 2248-2259. DOI: $10.1016 /$ j.jpowsour.2009.10.047

[20] Xu C., Faghri A. (2010). Mass transport analysis of a passive vapor-feed direct methanol fuel cell, Journal of Power Sources, Vol. 195, pp. 7011-7024. DOI: 10.1016/j.jpowsour.2010.05.003

[21] Kamaruddin M.Z.F., Kamarudin S.K., Masdar M.S., Daud W.R.W. (2015). Investigating design parameter effects on the methanol flux in the passive storage of a direct methanol fuel cell, International Journal of Hydrogen Energy, pp. 1-12. DOI: 10.1016/j.ijhydene.2015.06.071

[22] Xu C., Faghri A. (2011). Analysis of an active tubular liquid-feed direct methanol fuel cell, Journal of Power Sources, Vol. 196, pp. 6332-6346. DOI: 10.1016/j.jpowsour.2011.03.038 